\title{
ДЕНОТАТНІ ОЗНАКИ ПРИМУСУ У ВИРІШЕННІ ПРАВОВИХ КОНФЛІКТІВ
}

Черповицький М. Ю.

У статmі досліджено денотатні ознаки примусу у вирішенні правових конфліктів. Встановлено, що основою розкриття проблеми стали теорії верховенства права, поділу публічної влади, механізму реалізації права, юридичної відповідальності та інші. У правовій доктрині вживається відразу увесь масив термінів, яким номінують ключове поняття предмету дослідження. Згідно з законодавчою термінологією поширеними залишаються терміни «конфлікт» та «спір». Підкреслено, що ключовим елементом механізму вирішення конфлікту стає примусовий спосіб правореалізації. Примус розглядається як суть правової енергії, що поєднує соціальну природу людей, яка виражається у їхніх потребах жити спільно й злагоджено, задовольняючи власні інтереси. Серед визначальних ознак примусу у вирішенні правових конфліктів виокремлено урегульованість нормами права понять, повноважень учасників, стадій та процедур, форм та змісту документів, строків та інших питань. Визначено, що публічна влада стає посередником вирішення правових конфліктів. При цьому держава уповноважує інших суб'єктів на участь у вирішенні правових конфліктів через механізми ліцензування, сертифікацію та інші провадження. Наголошено, що до специфічних ознак досліджуваного muny примусу додаються загальні характеристики властивостей процесу вирішення позаправових та усіх інших типів соціальних конфліктів. Серед цих ознак найголовніші $\mathrm{mi}$, що стосуються суб'єкта, об'єкта правового конфлікту, їхніх внутрішніх змістовних рис. Специфічним також стає протилежність інтересів конфліктуючих сторін, їхнє спрощене сприйняття шляху до отримання потрібного об'єкта. Невміння розкладати конфліктну ситуацію на складові частини та серед них вичленувати проблемний складник вимагає залучення публічної влади. Як сторони конфлікту, так і держава часто обмежені у можливостях успішно вирішити конфлікт через недоліки норм чинного законодавства, нестачу кваліфікованих посередників і тому подібне.

Ключові слова: верховенство права, відповідальність, інтерес, правовий конфлікт, правопорушення, примус, публічна влада, спір, суд.

\section{Cherpovytsky M. Yu. Denotative signs of coercion in} resolving legal conflicts

The article reveals the denotative signs of coercion in resolving legal conflicts. It is established that the basis for solving the problem were theories of the rule of law, the separation of public power, the mechanism of law enforcement, legal liability and others. The legal doctrine uses the whole array of terms that nominate the key concept of the subject of study. According to legal terminology, the terms "conflict" and "dispute" remain common. It is emphasized that the key element of the conflict resolution mechanism is the forced way of law enforcement. Coercion is seen as the essence of legal energy, which combines the social nature of people, which is expressed in their needs to live together and in harmony with their own interests. Among the defining features of coercion in resolving legal conflicts are the settlement by law of concepts, powers of participants, stages and procedures, forms and content of documents, deadlines and other issues. It is determined that public authorities become a mediator in resolving legal conflicts. At the same time, the state authorizes other entities to participate in resolving legal conflicts through licensing, certification and other proceedings.

It is emphasized that the general characteristics of the properties of the process of resolving extrajudicial and all other types of social conflicts are added to the specific features of the studied type of coercion. Among these features, the most important are those that relate to the subject, the object of legal conflict, their internal content. Also specific is the conflict of interests of the conflicting parties, their simplified perception of the path to obtaining the desired object and the lack of understanding of the unity of opposites.

The inability to decompose the conflict situation into its constituent parts and to single out the problematic component among them requires the involvement of a judge or another third party on the part of the state. Both the parties to the conflict and the state are often limited in their ability to successfully resolve the conflict due to shortcomings in current legislation, lack of qualified mediators and the like.

Key words: rule of law, responsibility, interest, legal conflict, offense, coercion, public authority, dispute, court. 
Постановка проблеми та іï актуальність. Загальною ознакою предметного поля примусу визнається підпорядкування волею одного суб'єкта права волі іншого суб'єкта права (їхньої множини). При цьому примус, опосередкований правом, додає йому ознаку загальної обов'язковості та силу кожної наступної властивої праву риси - нормативності, формальної визначеності меж, детермінованості державою та ін. Як слушно відзначила Т.О. Коломоєць, примус, який здійснює держава в межах та на засадах, чітко визначених законодавством, можна вважати засобом забезпечення правопорядку, дотримання вимог, визначених нормами права [1, с. 64]. Юридичні правила під час конфлікту розцінюють як механічні алгоритми, які дають можливість створювати фактуальні положення [2, с. 43]. Це також можуть бути вимоги або приписи емпіричної підтримки правозастосування (апріорі примусового за визначенням), релевантність яких демонструється підсумковою ефективністю досягнутого консенсусу між конфліктуючими суб'єктами.

Водночас у сучасному світі держава далеко не єдиний, а у разі з сімейними відносинами взагалі допоміжний i/або непотрібний інститут примусу. Сім'я, коло близьких осіб, трудовий колектив, етнічна, релігійна та інші соціальні спільноти - це джерело нормативів, на які першочергово спирається людина. Їхня правосвідомість (правова культура) здійснює на неї найбільший вплив, з яким вона рахується - погоджується, дискутує, знаходить спільні точки дотику для порозуміння на взаємовигідних засадах. Зростання популярності людини у соціумі, наприклад, в силу значущості для публічного i/або політичного інтересу iї діянь, залучає до індивідуального правового простору нових суб'єктів права, пропорційно такій значущості. Громадськість намагається вплинути на людину, нав'язати йй своє бачення правових принципів, цінностей, норм та інших складових правопорядку. Протистояння людини (інших суб'єктів права) не властивим їхній природі правилам суть різних стадій правового конфлікту. Власне, суспільство перманентно перебуває у стані визначення змісту взаємозв'язків людини з правом, державою та іншими феноменами культури. Їхня конструктивність чи контрпродуктивність, необхідність або штучність й інші характеристики ключові для корегування процесу перебігу та вирішення правового конфлікту у напрямі, що зумовлює (складає частинку) сталого прогресу, а тому знання про них актуальні для адекватного розуміння кож- ного й особливо посадових осіб органів публічної влади.

Аналіз останніх досліджень i публікацій. Правова доктрина достатньо ґрунтовно насичена працями $з$ проблематики правих конфліктів і юридичного примусу. Адекватний відгук у правовій доктрині зазначеної проблематики знаходимо у численних працях таких учених, як С.С. АлексєєВ, Ю.П. Битяк, С.В. Бобровник, С. М. Братусь, М.В. Вітрук, М.І. Козюбра, Т.О. Коломоєць, В.К. Колпакова, О.Е. Лейст, Н.М. Оніщенко, Н.М. Пархоменко, С.П. Погребняк, О.Д. Тихомиров, Л.Г. Удовика, О.Н. Ярмиш та ін. Так, С.В. Бобровник здійснила ґрунтовне дослідження компромісу й конфлікту в праві; А.П. Гончарук проаналізував механізм правової поведінки; М.Б. Майка - виконання ухвал суду у цивільному процесі; М.М. Магомедрасулов - особливості примусу у правовій державі; Н.В. Макарейко - межі державного примусу; Ю.В. Малишева - цілеспрямовані санкції та їх застосування Радою Безпеки ООН; К.В. Куцик - заходи процесуального примусу в цивільному судочинстві; А.В. Сліденко - захист інтересів платників податків при застосуванні заходів податкового примусу; А.Х. Степанюк - сутність та принципи кримінально-виконавчої діяльності; М.М. Терещук - юридичну відповідальність у публічному праві; Л.Г. Удовика - правові конфлікти між різними типами правових систем [3] та інше. Водночас інтерпретація змісту правових конфліктів і примусу у правових дослідженнях не стала вичерпною, а тому робота у межах заявленої теми актуальна й дозволяє наблизити відбиття специфіки ознак примусу у вирішенні правових конфліктів в сучасних умовах. Як і будь-яка робота такого рівня, вона не покликана відобразити всі сторони проблеми, але дозволяє чітко виявити iї системоутворюючі характеристики у заданому напряму.

Мета статті - розкрити денотатні ознаки примусу у вирішенні правових конфліктів.

Виклад основного матеріалу. Характеризуючи обраний нами предмет дослідження, відразу зазначимо, що пізнання дивергентних ознак «примусу у вирішенні правових конфліктів»; специфіки прояву у досліджуваному предметі ознак, спільних для усіх соціальних конфліктів як таких, - передбачає усвідомлення його сутності та змісту, й, відповідно, формально- й діалектикологічних меж (обсягу). Вони виявляють себе як у співвідношенні з суміжними поняттями - розбіжності, протиріччя, звада, спір, сварка, зіткнення,

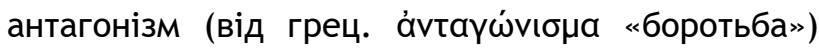


тощо, так й через асинхронну дію складників конфлікту. Формально-юридичний зріз досліджуваного питання виявляє поширеність термінів «конфлікт» (наприклад, у Кримінальному кодексі України від 05.04.2001 № 2341-ІІІ вживається у словосполученнях «збройний конфлікт», «воєнний конфлікт»), «спір» (у Сімейному кодексі України відносно батьківства, материнства, майна, місця проживання дитини та інших питань). Для чинних процесуальних кодексів нашої країни термін «спір» став ключовим.

Вбачається участь держави у вирішенні правових конфліктів. На досудовому етапі їхнього розв'язання беруть участь усі органи публічної влади, які тією або іншою мірою покликані узгодити соціальні інтереси різних громадян (їхніх спільнот). Метод примусу вважають найстарішим з методів, що використовуються для реалізації адміністративної функції держави. Серед його особливостей виокремлюють державно-владний характер застосування саме органами, відповідальними за певну сферу суспільних відносин; практично необмежене коло осіб, щодо яких можливо застосування адміністративного примусу; широка цільова спрямованість, яка полягає не тільки у покаранні, а й у попередженні протиправних діянь та інших негативних наслідків; відсутність підпорядкування між суб'єктами адміністративного примусу та особами, які вчинили правопорушення; широта можливих заходів, у яких може проявлятися адміністративний примус - сукупність примусових повноважень, об'єднаних у певну галузь державного управління, завдання яких полягає в охороні громадського порядку та спокою, шляхом обмеження природної свободи індивіда адміністративними засобами [4, с. 57, 186]. Цей тип примусу також визначають як захід органу управління до безпосереднього порушника адміністративно-правової норми вчинений з метою попередження правопорушень, забезпечення громадської безпеки та порядку, встановлений законом або підзаконним нормативним актом [5, с. 93].

Невирішені публічною адміністрацією невійськові правові конфлікти в межах території i/ або відносно громадян країни вирішуються через органи судової влади. Як влучно підсумовують вчені, проблема судової влади може полягати не стільки у гострій нестачі кадрів, скільки у штучному створенні проблем, які виникають через невиконання органами державної влади своїх прямих конституційних обов'язків. А це своєю чергою призводить до посилення навантаження на суди. I відповідальність за це мають нести не суди і органи суддівського врядування, а чиновники та відповідні органи державної влади. Надмірне навантаження суддів, зумовлене нестачею кадрів у судах, збільшується в тому числі через невиконання органами державної влади своїх прямих конституційних обов'язків. Звернень до суду було б менше, аби чиновники добросовісно виконували посадові обов'язки [6]. Послідовне застосування закону на принципах рівноправності (однаковості за одні й ті самі діяння, у типових правових ситуаціях) дозволяє громадянам жити в безпеці від повсякденного насильства та образ незалежно від того, наскільки могутня інша сторона (ворог). У відповідь люди довіряють публічній владі та дотримуються законів (виконують їх), чим роблять закони сильними для протистояння сваволі фінансово спроможного, корумпованого i/або іншого порушника права [7, с. 146].

Пропорції участі органів публічної влади у попередженні та вирішенні правових конфліктів різною мірою співвідносяться із мірою застосування примусу i/або заохочення до примирення конфліктуючих сторін. Якщо на етапі профілактики правового конфлікту методи заохочення та стимулювання домінуючі, то у подальшому під час досудової медіації ці методи щонайменше врівноважені примусом, а вже на етапі судового розгляду справи процесуальні рішення цілковите втілення унормованого правом примусу держави. Соціальна місія суду, вочевидь, не заохочувати, стимулювати, вмовляти громадян та інших конфліктуючих суб'єктів права, а змушувати їх дотримуватися норм правових законів як наслідку його правоінтерпретаційної та правозастосовної діяльності. Важливо, що суд стає органом примусу не тільки відносно суб'єктів приватного права, проте таку саму роль виконує й відносно органів публічної влади. Натомість парламент, публічна адміністрація, муніципальна влада і/або будь-хто інший таких повноважень щодо суду не має.

Описані взаємозв'язки частина теорії верховенства права. Розподіл повноважень між гілками державної влади $\epsilon$ інтегральною рисою верховенства права. Тому дотримання принципу верховенства права накладає правові обмеження на виконавчу гілку влади, оскільки вона не може функціонувати поза конституцією та поза місцем, визначеним для неї поділом державної влади. Здійснення державної влади відповідно до конституційних приписів, зокрема на засадах її поділу на законодавчу, виконавчу та судову, завдяки визначеній основним законом держави системі 
стримувань і противаг забезпечує стабільність конституційного ладу, запобігає узурпації державної влади та узурпації виключного права народу визначати і змінювати конституційний лад в країні. Саме органи судової влади і конституційного контролю виконують, зокрема, основні функції належного правового стримування законодавчої і виконавчої влади, а також контролю за діяльністю цих гілок влади з метою недопущення виходу за межі повноважень. Діяльність органів судової влади полягає в контролі за дотриманням законності, а конституційного контролю - в конституційності діяльності органів законодавчої та виконавчої влади. Органи судової влади і конституційного контролю $є$ противагою законодавчій та виконавчій владі, оскільки можуть переглядати акти цих гілок державної влади щодо законності або конституційності [8].

Баланс розподілу ролей у всіх цих етапах вирішення правових конфліктів перманентно відтворюється тільки у цивілізаціях високої правової культури, які вміло й прагматично нашарували на продуктивну основу духу своєї нації (народу, етносу тощо) прогресивні законодавчі механізми врегулювання суспільних відносин. По факту розкрили правове у своїй натурі та спромоглися формально-визначити це у нормах права, які чинні й забезпечені передусім правосвідомістю людей, оскільки законодавство й практика його реалізації антроповимірні [9]. Людина тут являє собою соціалізовану особистість, яка стає у суспільстві такою через самоусвідомлення, вияв індивідуальності духу як основи права. Уповноважена та дисциплінована правом особа основа правопорядку, а разом із суспільством вони складають основи ще й держави [10, с. 335]. Водночас українська та інші транзитивні правові системи характеризуються переважним протистоянням (замість співробітництва) політичних сил, декомпозицією прогресивних моделей поведінки, фрагментарним правонаступництвом й тривким (замість сталого) відтворенням благ, ручним (адміністративним) й відсталим способом управління (замість інституційного).

Інституційно механізм примусу характеризують не тільки суб'єкти та порядок черговості їхньої участі у правозастосуванні, але й змістовні характеристики способу та вичерпного переліку дій, які закон вимагає вчинити у чітко визначеному порядку. Наприклад, поліцейський примус до виконання норми закону на початку вчиняє не через складання протоколу про правопорушення чи винесення документу (постанови або інше) про накладення санкції правової норми (наприклад, штрафу) на правопорушника, а через усне попередження чи, що ще краще, профілактику делінквентної (лат. delictum - проступок, англ. delinquency - правопорушення) поведінки громадян. Й надалі, якщо загроза праву не зникла, застосовує по черзі більш суворі заходи правового реагування. Зауважимо, що обрання найбільш дієвого з позиції права інструменту для дії правоохоронця (судді та ін.) зумовлене обставинами життя (справи), у яких уповноважена на застосування примусу посадова особа держави опинилася. Оцінка цих обставин класично здійснюється за суб'єктно-об'єктним складом правовідносин та їхніми сутнісними характеристиками. Закон у цьому разі далеко не завжди універсальний інструмент, що дозволяє знайти відповідь на усе різноманіття неправових викликів для органів правопорядку, тощо. У цьому зв'язку актуалізується проблема розвитку правової свідомості та інтуїції (здатності виходити за межі досвіду) [11, с. 454] таких осіб на рівні, що детермінує ефективність їхнього правозастосування.

У законах виписані випадки зупинки громадян для перевірки документів, що посвідчують особу; затримання; огляду речей, транспортних засобів, документів; обшуку тощо. Критично важливими для верховенства права людини залишаються випадки правомірного застосування органами правопорядку фізичного й психічного примусу, спеціальних засобів, вогнепальної зброї, а прокурорами затвердження обвинувальних висновків відносно дійсно (не хибно заявлених) винних осіб й, відповідно, суддями притягнення винних до відповідальності або негайне й безумовне виправдування невинних, присудження до стягнення належного за правом коштів, майна, визначення механізму реалізації батьківських прав, прав дитини, права на сім'ю (часу, змісту вчинюваних дій, наприклад, конфліктуючого подружжя) і таке інше. Питання людської свободи та меж суб'єктивних прав - предмет спрямування зазначених повноважень держави. Межі цих повноважень не більші, ніж потрібно для підтримання правопорядку відтворення й розвитку благ, у тому числі їхнього рівного й справедливого обліку, накопичення та розподілу на засадах верховенства права.

Ускладнення людської цивілізації, починаючи від епохи модерну (межа XIX-XX ст.) й дотепер призвело до громіздкості догми закону. На цій основі пришвидшення темпів розвитку людства тільки послаблює ефективність законодавчих механізмів, роблячи людину вразливішою до 
зовнішніх загроз іiі природним правам. Розхитані усталені правові механізми врегулювання суспільних відносин - втрачені звичаї, зростаючі прогалини у праві, які заміщує насильство, мораль (міфи, релігія і т. п.), корупція - зумовлюють хиткість цих механізмів, їхню перманентну відсталість від викликів часу та, як результат, зростання напруження у суспільстві. Його конфліктний потенціал зростає, проявляючись через протистояння - громадян один з одним, етнічні, національні, міждержавні та інші. Увага правників концентрується на змісті цих коливань правової матерії та місцях вирішення конфлікту - вибуху його рішеннями сильнішого за аргументацією чи силою (фінансовою, фізичною, військовою тощо).

Відмова від лінійного розуміння детермінізму у праві [12, с. 50] демонструє коливання норм-заборон й норм-дозволів між межами абсолютної свободи людини (ї̈ спільнот) та публічно-владними функціями держави інструмент, за посередництва якого керуюча система (суб'єкт правового регулювання) і керована система (об'єкт - правові відносини) мають результат взаємного впливу (публічно-владного управління/впливу, публічно-приватного партнерства, комунікації тощо) у вигляді зміни об'єкту. У нашому випадку вирішення правового конфлікту - центральна ланка цих змін. А оскільки це конфлікт, то, за визначенням, він являє точку (відрізок) напруження правової енергії громадян - біфуркації (від лат. bifurcus «роздвоєний»), де суспільство виявляє здатність ідентифікувати й конструювати себе, виходячи з наявних правових моделей поведінки у конфліктах тощо [13, с. 82].

Зазначені правові флуктації (від лат. fluctuatio коливання) та викликані ними конфліктні стани через різновекторну дисипацію (переходи та розсіювання) енергій людей зумовлюють стан, коли вирішення правового конфлікту відбуваються не самі по собі, а під впливом волі уповноважених народом посадових осіб держави. Технічно їхя правосвідомість віддзеркалює зміст зафіксованих у конституції домовленостей громадян один з одним про концептуальні правила поведінки у вигляді норм-принципів, норм-декларацій, норм-цілей, а далі транслює їх у реальність соціальної взаємодії. Роль держави тут у погодженні інтересів різних соціальних верств населення через осмислення та доведення до відома учасників конфлікту різних стадій (виникаючого, загостреного, затухаючого тощо) сутності та змісту людської єдності у конституційно зафіксованих правових основах.
Можна припустити, що адміністративний, судовий та інший публічний примус (що полягає в застосуванні до суб'єктів, які вчинили правопорушення у сфері здійснення державних функцій, передбачених нормами права заходів покарання, перевиховання та спонукання до діяльності, спрямованої на усунення шкоди, заподіяної такою поведінкою [14, с. 70]) тим сильніший, ніж більша неадекватність у сприйнятті конфліктуючими сторонами конституційно відображених правових цінностей. Власне зневажання аксіологічними підвалинами права у законодавчому полі розгорнуто у вигляді спеціальних їхніх норм-охорона, a саме: життя, особистої недоторканості, фізичної цілісності та неушкодженості, статевої недоторканості, права власності, національної безпеки, публічних фінансів та інші об'єктні підстави рубрикація кримінального кодексу, інших законів, які містять норми, що захищають суспільство від деліктів (лат. delictum - проступок, правопорушення). Відповідно, й кількісно примус переважає у правозастосуванні тим більше, чим потужніша руйнівна сила порушника. І ось кількісний перехід невирішених договірним чи примусовим способами конфліктів переходить у якість потужного i/або тривалого примусу різної фактури, де війна (військові / воєнні операції тощо) остання ланка у його будові, яка виключає право з поняття «правовий конфлікт», залишаючи тільки слово «конфлікт», під час перебігу якого примус - вже не втілення уповноваженої народом волі публічної влади, а домінантне уособлення насильства і свавілля.

Описані взаємозв'язки дають можливість вбачати необхідність для публічної влади профілактичної функції - недопущення правопорушень, нейтралізація чи ліквідація причин та умов, що породжують або сприяють їхньому вчиненню (деліктний вимір) [15, с. 19]; підтримання балансу інтересів у суспільстві (управлінський та контрольний виміри публічно-владного впливу). Іٓї актуальність завжди нагадує про себе прикладами з вітчизняної та історії інших країн, де зволікання з правами людини мало наслідками революції (заколоти, повстання, війни тощо), що послаблювало у підсумку не просто державу, а й усі націю, яка на міжнародній арені виявлялася швидше формою, аніж змістом права. Довіра добре поінформованого, розсудливого й законослухняного населення до публічної влади - це наслідок її професійної (у тому числі своєчасної) роботи та запорука їі сили, зокрема й у зовнішніх відносинах. Тут переконання, партнерство й диспозитивні 
засади взаємодії населення й держави - головні складники їхнього відповідального ставлення одне до одного.

У ретроспективному вимірі юридична відповідальність найбільш поширений засіб державного примусу до правопорушників [16, с. 190], що застосовується для забезпечення громадського спокою, попередження майбутніх правопорушень, виконання актів державного управління (адміністративних актів) [4, с. 61]. Накладаючи санкції на правопорушників, наявний конфлікт вирішується повністю або тільки згасає частково. Зв'язки досліджуваного концепту виявляють себе й у межах юридичної відповідальності за наслідки власних діянь (дій та бездіяльності), а саме: публічної влади - єдиного суб'єкта, уповноваженого на застосування примусу - щоб об'єктивно виправданий часом та обставинами, домірний (пропорційний) примус здійснювався у правових рамках та був спрямований на досягнення правової мети; громадян та інших суб'єктів права докладати максимум зусиль, щоб свідомо й повноцінно діяти у межах права, зважуючи на свої людські чесноти й не потураючи вадам.

Висновки. Отже, порушені у цій роботі питання розгортаються на тлі теорій верховенства права, поділу публічної влади, механізму реалізації права (у тому числі правозастосування), юридичної відповідальності та інших суміжних їм положень правової доктрини. Тут вживається відразу увесь масив термінів, яким номінують ключове поняття предмету нашого дослідження. Водночас у законодавстві поширеними залишаються терміни «конфлікт» та «спір». Ключовим елементом механізму вирішення спору (конфлікту) стає примусовий спосіб правореалізації. Примус суть правової енергії, що поєднує соціальну природу людей - їхні потреби жити спільно, злагоджено задовольняючи власні інтереси.

Серед визначальних ознак примусу у вирішенні правових конфліктів виокремлюємо урегульованість понять, повноважень учасників, стадій та процедур, форм та змісту документів, строків та інших питань нормами права. До цього додаємо опосередкованість вирішення за участі публічної влади, у тому числі уповноважених нею через ліцензування, сертифікацію та інші контрольні (атестаційні) провадження суб'єктів. Специфічні ознаки досліджуваного типу примусу доповнюються загальними характеристиками властивостей процесу вирішення позаправових та усіх інших типів соціальних конфліктів: а) суб'єктно-об'єктним складом; б) протилежністю інтересів кон- фліктуючих як спрощене сприйняття шляху до отримання жаданого об'єкта (відсутність розуміння єдності протилежностей; в) невмінням деконструювати контпродуктивне й відтворювати натомість зростання блага спільними зусиллями через концентрацію ресурсів усіх сторін конфлікту в межах композиції зняття деструктивності проявів характерних ознак протилежностей - тверджень, діянь тощо); г) домінуванням волі більш сильного (за параметрами розвитку особистісних й професійних інструментів онтологічно природного примусу, пригнічення волі протилежної сторони / суперника - інтелекту, волі, сенситивності; i/або цивілізаційно й історично детермінованих ресурсів для примусу - фінансового капіталу у поєднанні з фізичною, військовою силою) або консенсуального паритету (максимальне урахування інтересів кожного); д) структурованістю застосування примусу у процесі вирішення правового конфлікту - здійснення дій (утримання від них) і часові проміжки для цього чітко алгоритмізовані, поєднані синхронною активністю (взаємними реакціями) усіх учасників процесу тощо.

\section{Література}

1. Коломоєць Т.О. Адміністративний примус у публічному праві України: теорія, досвід, та практика реалізації : монографія. Запоріжжя : Поліграф, 2004. 404 c.

2. Баранова Ю.О. Методологічні правила порівняльно-правових досліджень : дис. на здобут. наук. ступ. канд. юрид. наук : 12.00.01. Одеса. 2015. 193 с.

3. Удовика Л.Г. Правова система України : глобалізаційні трансформації. Запоріжжя : КСК Альянс, 2014. 320 c.

4. Піляй А.М. Ґенеза та сучасний стан адміністративної функції держави : дис. на здобут. наук. ступ. канд. юрид. наук : 12.00.07. Київ, 2020. 216 с.

5. Советское административное право : учебник / под ред. С.С. Студеникина. Москва : Госюриздат, 1958. 300 c.

6. Прудивус 0. Неналежне виконання державними посадовцями своїх обов'язків значною мірою збільшує навантаження на суди. Вища рада правосуддя. 24.12.2020. URL : https://court.gov.ua/press/ news $/ 1047228$

7. Гаудер П. Верховенство права в реальному світі / пер. з англ. : Д. Вовк (наук. ред.) та ін. Харків : Право, 2018. 392 с.

8. Щодо відповідності Конституції України (конституційності) окремих положень Закону України „Про запобігання корупціі“, Кримінального кодексу України : Рішення Конституційного суду 
України від 27.10.2020 № 13-р/2020 у справі за конституційним поданням 47 народних депутатів України. URL : https://zakon.rada.gov.ua/laws/show/ v013p710-20\#Text.

9. Макаренков О.Л. Кореляція між антропним та публічними інтересами в антикорупційних трансформаціях правової системи відкритого суспільства. Право та державне управління. 2020. № 1. С. $90-98$.

10. Кистяковскій Б.О. Соціальныя науки и право. Очерки по методологіи соціальныхъ наукъ и общей теоріи права. Москва : Изданіе М. и С. Сабашниковыхъ, 1916. 704 с.

11. Большой энциклопедический словарь. Гл. ред. А. М. Прохоров ; Редкол. Н. М. Ланда, и др.. Изд. 2-е, перераб.и доп. Москва : Большая Рос. энцикл.; СПб. : Норинт, 2004. 1456 с.

12. Кривцова І.С. Методологічна роль синергетики у порівняльно-правовому пізнанні : дис. ... канд. юрид. наук: 12.00.01. Одеса, 2008. 233 с.
13. Турен А. Возвращение человека действующего. Очерк социологии. Москва : Научный мир, 1998. 204 c.

14. Білозьоров Є.В., Власенко В.П., Горова О.Б., Завальний А.М., Заяць Н.В. та ін. Теорія держави та права : навчальний посібник / за заг. ред. С.Д. Гусарєва, О.Д. Тихомирова. Київ : НАВС, Освіта України, 2017. 320 c.

15. Миколенко О.М. Функції адміністративноделіктного права (теоретико-правовий аспект) : автореф. дис. ... докт. юрид. наук : 12.00.07. Запоріжжя, 2020. 38 с.

16. Тодыка Ю.Н. Конституция Украины - Основной Закон государства и общества : учеб. пособие. Харьков : Факт, 2001. 382 с.

Черповицький М. Ю., аспірант кафедри історії і теорії держави та права Запорізького національного університету 